\title{
AKADÉMIÁNK ÉS AZ INFORMÁCIÓS VILÁG
}

\section{OUR ACADEMY AND THE WORLD OF INFORMATION}

\author{
Vámos Tibor \\ az MTA rendes tagja, professor emeritus, MTA SZTAKI \\ vamos@sztaki.mta.hu
}

ÖSSZEFOGLALÁS

Villámnézet az információs világ és akadémiánk viszonyairól, az emberi tényezőkkel kapcsolatos legfontosabb feladatokról és a robotvilágról szóló hisztériákról.

ABSTRACT

A short flash on the relation of our Academy and the World of Information, on the most important tasks concerning the human aspects and the world of robots hysteria.

Kulcsszavak: információs világ, emberi tényező, automatizálás, mesterséges intelligencia

Keywords: world of information, human factor, automatization, artificial intelligence

Kibernetika? Burzsoá áltudomány, ezzel kezdődött a válasz a szovjet birodalomban arra az Amerikában elindult történelmi forradalomra, amelynek jelentőségét, méreteit ott sem tudták felmérni, ahol elkezdődött, és azok sem, akik megalapozták.

A feleszmélés errefelé körülbelül egy évtized késéssel indult, a rendszert időnként rázogató reformmozgalmak során. Itthon nem sokkal 1956 első tanulságainak bátortalan és ellentmondásos emésztése idején, nem véletlenül az Akadémián és az ipari vezetés reformköreiben. Az utóbbi egy másik, többé-kevésbé jól feldolgozott történet, amely néhány nyugati számítógép importjával és az azok körül gyülekezőkkel indult, a mienk a Rákosi-börtönből szabadult Tarján Rezsővel és a csodásan forgó agyú Kalmár Lászlóval, majd egy kibernetikai kutatócsoport alakításával. Itt hamar összegyültek a nagyra hivatott ifjú tehetségek, akik messze látóan érezték a máig kibontakozó fejlődést, így az operációkutatásban, azaz a folyamatok optimális tervezésében úttörő Prékopa András, majd Kornai János, a nyelvészetben Kiefer Ferenc, a szoftvereknél Dömölki Bálint. A későbbi évek sok 
és értékes alkotócsapata kapcsolódott hozzájuk, itt töltötték tanuló éveiket. A korai szellemi pezsgést mutatja, hogy az őstörténet naiv számítógép-építési kísérlete mellett még zenei struktúraelemzés is született. Az akadémiai intézménylétesülés a SZTAKI (Számítástechnikai és Automatizálási Kutatóintézet) és a KFKI (Központi Fizikai Kutatóintézet) kereteiben teljesedett ki.

Meg kell jegyeznünk, hogy ezeknek az új diszciplínáknak a helyei Akadémiánkon még mindig nem teljesen elfogadottak, ezért is fontos a most induló interdiszciplináris kezdeményezés, amelyben a történet feldolgozott anyagainak gyüjtése és újraértékelése fontos feladat a lemaradásaink és további lehetőségeink vizsgálatában.

Szerintem ezekben a ma és föleg a közel-holnap legnagyobb kérdése az emberi szerep. Ma ez két póluson jelentkezik, a szakemberhiányban és a ma már igényesebb feladatok elvégzésére alkalmatlan underclass milliós tömegében. A holnap, azaz a közvetlenül következő néhány évtized kegyetlenebb és kegyesebb lehet. Az automatizálás feltartóztathatatlan technológiai és minden tevékenységet érintő folyamata kiszorítja a társadalmak többségét mai munkakörülményeiből, és közben változó feladatokat teremt egy egyfelől szórakoztató és szórakozó világnak, másfelől a mély tartalmú humán szolgáltatásoknak. Mindez már ma meg kell hogy mozgassa a természettudományok és a társadalomtudományok újonnan alakuló egészét.

Ahogy a politikában, úgy ebben is felmerülnek figyelemelterelö nézetek. Sokszor igen tekintélyes, alkotó tudósok is beleesnek a tömegcsábító érdekesség és híresség csapdájába. A rém az embereket először csak helyettesítő, majd felülmúló, pusztító robot és annak mesterséges intelligenciája. A mítoszok és egyéb fantazmagóriák eljövendő világát nehéz logikai módszereinkkel kizárni. Részben elegendő, ha ezeket a bizonyíthatatlanság agnosztikus válaszával határoljuk el valós teendőinktől. Van sok ellenérvünk is, hiszen az ember és a gép két nagyon különböző fejlődés eredménye, az egyik az evolúció sok millió éves, izgalmasan összetett, jóval, rosszal kevert és azokat ôrző szülötte, a másik egy korának válaszoló célszerkezet. Az agykutatás majdnem naponta tár fel újabb és újabb olyan bonyolultságokat, amelyek a belátható időben elérhető gépi reprezentációk számosságát messze meghaladják. Ezekben a számszerüségekben, a bonyolultságok becsléseiben is elengedhetetlen és szerencsére megállíthatatlan a kutatói kíváncsiság és eszközfejlődés.

A mai, útválasztásokat tükröző mítoszoknak is ősiek a gyökerei. Az egyik a Gólem, a félelmetes (a horrorfilmekben), a másik az Afrodité-kultusz körül alakult ideálkép, Pygmalion, Páfosz és Galatea története, a mủvészi alkotás csodájáé, a szépségé és a szerelemé, meg a máig élő kultúrvárosé. A mítosz Gólemét a bölcsesség egy mozdulattal megsemmisítette, a maiakat nehezebb lesz.

Mindennek feltétele a közös nyelv. Ma még egy-egy diszciplínán belül is nyitott probléma, akadálya az együttmüködéseknek, a részeredmények kölcsönös felhasználásából építkező tudásnak. Találkozzunk megértéssel! 